\title{
議長サマリー(仮即)
}

第7回アジア学術会議 1999年10月28日一-31日、東京

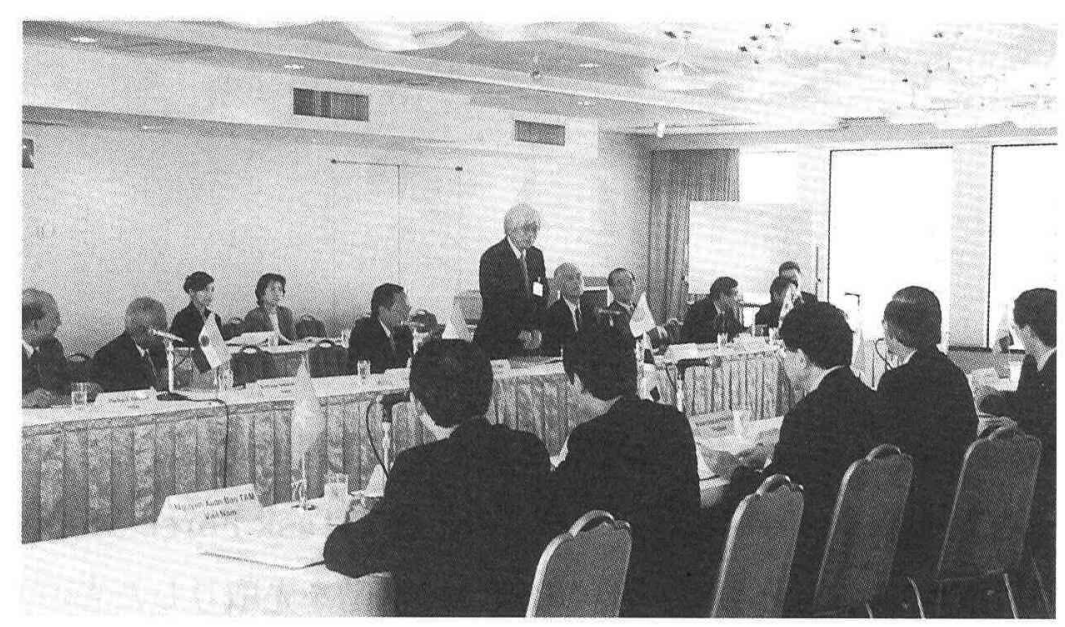

1

日本学術会議は1993年以来アジア学術会 7 回アジア学術会議は、京王プラザインターコンチ ネンタルホテルにおいて、1999年10月28日から31 日まで開催された。参加国は、中国、インド、イン ドネシア、韓国、マレイシア、フィリピン、シンガ ポール、タイ、ヴィエトナム、そして日本であった。 今回の会議の主要議題は、「インターアカデミー パネル（IAP）2000年会議への提言」及び「アジア 学術会議 (SCA) : 定款、ワークキングルール、及 び第1回会議のプログラム」の創設についてであ った。

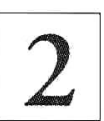

天皇皇后両陛下の御臨席の中、アジア学 術会議参加者は、10月28日に日本学術会議 講堂で行われた日本学術会議創立50周年記念式典 に出席し、天皇陛下の扣言葉を賜る栄誉に浴した。
日本学術会議の吉川会長の式辞に引き続き、小渆恵 三内閣総理大臣が挨摱を述べた。マレイシア科学ア カデミーのオマル.A.R.会長と前スウェーデン科学 工学アカデミー副会長であるカール J.オストロム 氏より祝辞が述べられた。式典に続いて三者による 特別記念講演が行われた。全米科学アカデミーのシ ヤーウッド・ローランド国際部長の講演論文「21世 紀の大気」が、東京大学の富永健教授により読み上 げられた。シンガポール科学アカデミーのレオ.W. H.タン会長は、「明日の科学者を育てる」のテーマ で講演し、日本学術会議吉川会長が「科学と社会」 についての講演を行った。

3 の項目が議論された。

（1）IAP 2000年会議への提言案について意見交換 が行われた。アジア学術会議参加各国は、IAP 2000 


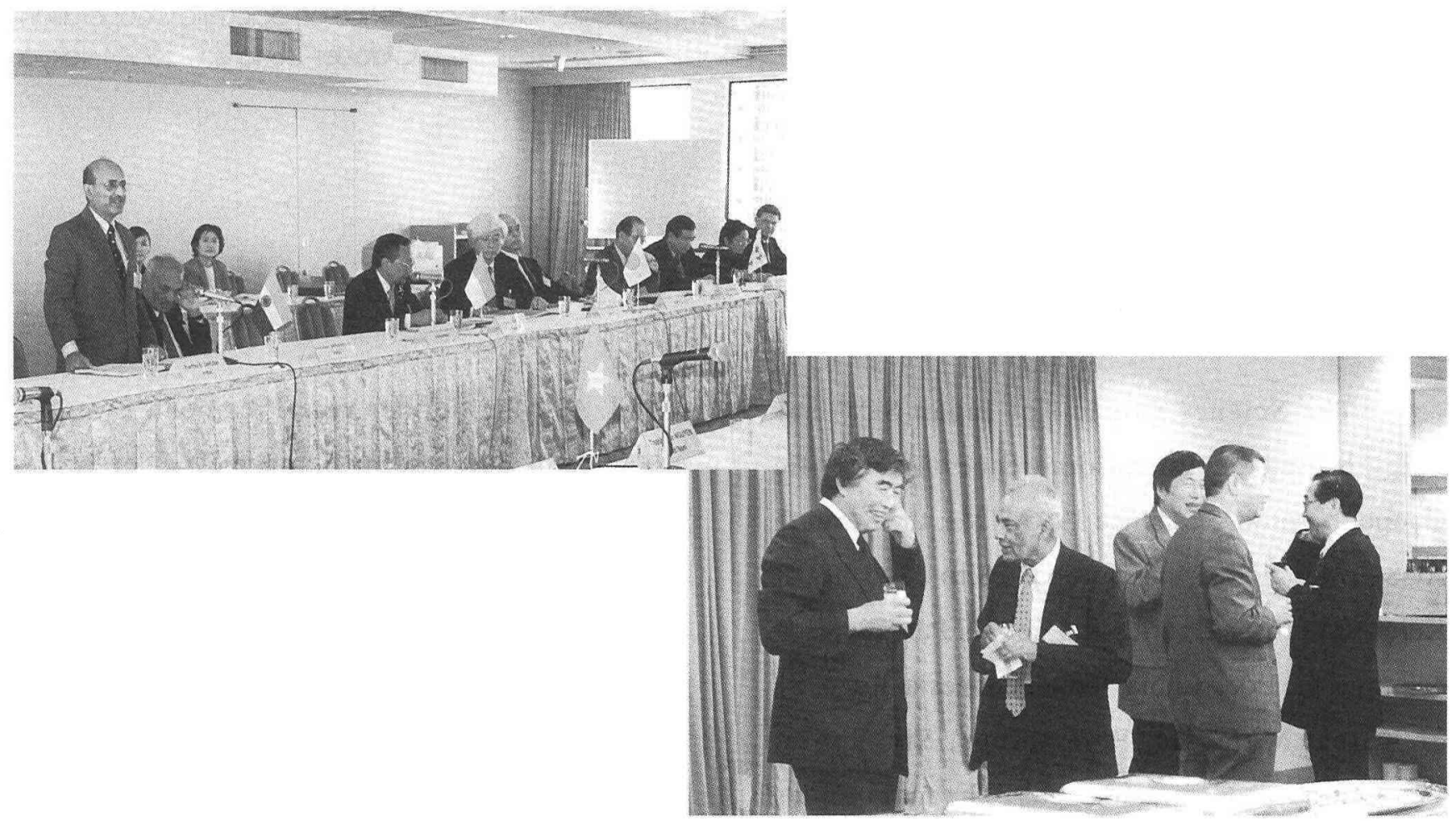

年会議のインプット内容についてさらに議論を重ね ることに合意し、最終案は、2000年2月マレイシア で開かれるタスクフォースミーティングにより作成 されることとなった。

(2) SCAワーキングルールに関して、討議が行われ た。日本学術会議の一団が、アジア学術会議 (SCA) 開 催のための準備・運営に関するワーキングルールの 実行について、主催国となる国々を訪問することも 考えられている。

（3）10月30日には、2001年にタイで開催される予 定の第 1 回SCA会議のテーマとプログラムについ て、タイから提案が出された。

（4）アジア学術会議（SCA）定款について議論が 行われた。日本学術会議が各国における適切な一機 関にその定款とともに手紙を送り、2000年5月に会 合が行われる暫定会議への国の代表の選考への助力 を依頼することが合意された。
4 において開催される。第8回アジア学術会議 の参加者はIAP 2000年会議に招かれる予定である。 5 第8回アジア学術会議をもってア $\mathrm{ACSC}$ ) の活動を終了することが再確 認され、SCA構想を実現するため、必要な検討を 推し進め、SCAを成功のうちに設立するため続いて の計画を開始することへの期待を表明した。 


\section{Chairperson's Summary}

The Seventh Asian Conference on Scientific Cooperation October 28 to 31, 1999 Tokyo

1 The Science Council of Japan(SCJ) has hosted the Asian Conference on Scientific Cooperation(ACSC) since 1993. This, the Seventh ACSC, was held from October 28 to 31,1999 at Keio Plaza Inter-Continental Tokyo. Participating countries included China, India, Indonesia, Republic of Korea, Malaysia, Philippines, Singapore, Thailand, Viet Nam, and Japan. The main topics of discussion at this conference were "Proposals for InterAcademy Panel(IAP) 2000 Conference" and establishment of "Science Council of Asia(SCA): Statutes, Working Rules and the program for the First Conference" .

2 In the presence of Their Majesties the Emperor and Empress, the ACSC participants had the honor of attending the 50th Anniversary Ceremony of the Science Council of Japan at the auditorium of SCJ on October 28, being graced to listen to the Words given by His Majesty the Emperor. After the opening address of Prof. Hiroyuki Yoshikawa, President of SCJ, the Prime Minister Mr. Keizo Obuchi made a speech. The congratulatory speeches were delivered by Tan Sri Datuk Dr. Omar Abdul Rahman, President of the Academy of Sciences Malaysia, and by Prof.
Karl J. Åström, Former Vice-President, Swedish Academy of Engineering Science. The ceremony was followed by three special commemorative lectures. Prof. Sherwood Rowland, Foreign Secretary, U.S. National Academy of Sciences, presented his paper on "Earth's Atmosphere in the 21 st Century", which was read by Prof. Takeshi Tominaga of The University of Tokyo. Prof. Leo W. H. Tan, President of Singapore National Academy of Science gave a lecture on the topic: "Motivating and Nurturing the Future Scientist". And Prof. Hiroyuki Yoshikawa, President of SCJ, delivered his lecture on "Science and Society".

3 The following matters were debated in the (1) Opinions were exchanged on the draft proposal for the IAP 2000 conference. ACSC countries agreed to discuss more about contents of input of IAP 2000 and final draft should be made by the Task Force Meeting which will be held in Malaysia in February 2000.

(2) SCA Working Rules were discussed. There is the possibility that a team from SCJ will visit some host countries regarding the implementation of the Working Rules for the Preparation and 
Administration of the SCA Conference.

(3) On October 30 a proposal was made from Thailand about the theme and program of the First SCA conference to be held in Thailand in 2001.

(4) Statutes of the Science Council of Asia were discussed. It was agreed that SCJ will write to an appropriate organization in the respective country with said statutes attached and request the latter to facilitate selection of the country's representative to the pro tem Council, which will meet in May 2000 .
4 The Eighth ACSC will be held in Tokyo in May 2000. Delegates for the Eighth ACSC will be invited to the IAP 2000 Conference.

5 ACSC, reconfirming to finalize its activity at the Eighth Conference, expressed expectations to launch the succeeding project to establish SCA successfully through furthering the necessary reviews to materialize the SCA framework.

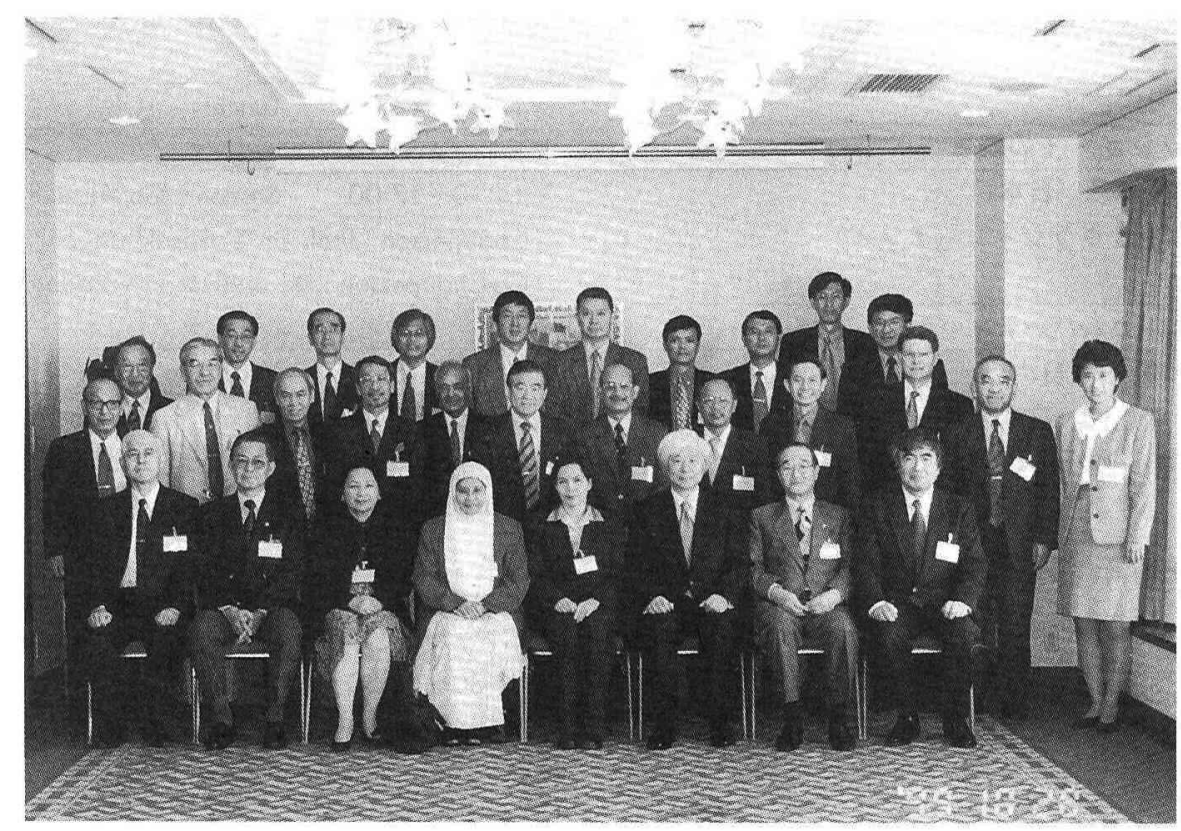

